Przegląd Badań Edukacyjnych Educational Studies Review

ISSN 1895-4308

nr 35 (2/2021), s. 235-253

METAANALIZY

BADAŃ

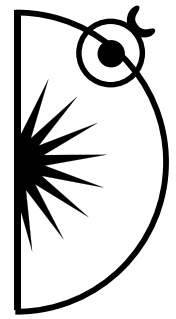

Ewa Jarosz

University of Silesia, Katowice, Poland

e-mail: ewa.jarosz@us.edu.pl

ORCID: https://orcid.org/0000-0002-3207-0148

\title{
Methodology of Modern Research Concerning Childhood - The Perspective of Childhood Studies
}

http://dx.doi.org/10.12775/PBE.2021.041

\begin{abstract}
:
Modern research concerning childhood has been developing mostly based on the concept of children's rights, which is seen not only in the topics of research but also in the objectives and methodological aspects. The aim of the paper is to show how respecting children's subjectivity and their right to voice opinions in matters that affect them are reflected in childhood studies by means of the specific epistemological perspective, which is seeing the reality through children's eyes, and the preference for some methodological solutions, i.e. the types of research and the applied methods that are useful in obtaining reports, opinions and assessment of children. The analysis of scientific and research discourse allowed identification of several preferred methodological types of childhood studies, i.e. ethnographic, meta-analytical using big data, survey and longitudinal research. It also allowed indication of the current which is developed in research on childhood and is related to promotion of participatory research with children.
\end{abstract}

Keywords: childhood studies, methodology, research with children, participatory research with children.

\section{Introduction}

The modern discourse on childhood studies is significantly based on the concept of children's rights. Of note, the origins of what is now referred to as childhood 
studies are linked to the development of many earlier currents of research on children. They are strongly associated with research on the history of childhood, including Philip Aries' groundbreaking views on childhood as a socio-cultural construct (Aries, 1995; Śliwerski, 2020), the development of the new sociology of the child (Corsaro, 2015), and ecological psychology (Melton et al., 2014). They are significantly based on the currents of anti-authoritarian and liberal pedagogy and the introduction of democratic ideas to educational relations promoted by thinkers and pedagogues, including Janusz Korczak. In general, childhood studies are rooted in all types of research on children and childhood, dating back to Darwin's work (Prout, 2005) and developing within the multidisciplinary interests of psychologists, pedagogues, sociologists and cultural researchers (Garbula \& Kowalik-Olubińska, 2012).

In its current form, the development of research on childhood began in the 1990s soon after the Convention on the Rights of the Child was adopted (Weller et al., 2014; Archard, 2015). According to researchers, the Convention, as an act of international regulation giving children a new legal and socio-cultural status, was a key factor for changes in the field of childhood research (Ben-Arieh, 2014). Not only did it give the impetus for the previous research on children, but it also had an influence on a change in its specificity, i.e. ontological and methodological identities, including a change in the way of its realization. The Convention expressed and imposed the necessity of respecting children's rights in research, i.e. giving them the subjective status and subjective participation in research, as well as the necessity of respecting children's rights in the context of the methods used in research (Beazley et al., 2009; Vanobbergen, 2015).

Research on the situation of children based on the imperative of children's rights referred to as childhood studies, children studies, children research is characterised by specific features. The identity of childhood studies was defined in the early descriptions of this research form that were published in the 1990s (James \& Prout, 1997, p. 8) and further textbooks (Qvortrup et al., 2009; Melton et al., 2014). Next to the ontological basis of childhood studies establishing the subjective and socially and culturally active status of the child and childhood as the essence of the reality under study (Honig, 2009), childhood studies are based on several fundamental principles. The first and the most important one is related to the teleological targeting of research to the identification of the manner of children's perception, evaluation and the meaning of reality and the adoption of this approach as the basic epistemological perspective. In childhood studies, the predominant methodological rule of the cognition of the reality is the perception and understanding of reality by children analysed on the basis 
of their direct reports, assessments and opinions expressed by children. The second fundamental feature is the principle of children's active participation in research not only to obtain from them direct reports on reality, but also to make them involved in data collection and even in the realization of the entire research process. The third principle is related to the social significance and impact of research, which means that such research is fundamentally aimed at changing the situation of children (Morrow, 2008) and is focused on improving their situation. Therefore, it is believed that the basic aim of childhood studies is to be praxeologically oriented (Weller et al., 2014). As the specificity of the research conducted within the childhood studies profile, its feature of interdisciplinarity is also emphasised, which means the involvement of different disciplines and professionals representing different points of view in research on children and the holistic assessment of children's situation or problems (Prout, 2005; James \& James, 2008; Melton et al., 2014; Moody \& Darbalay, 2019). High ethical standards on the applied methods and the rule of a subjective approach to the children under study are also significant specific features of this current of research (Hill, 2005; Beazley et al., 2009; Ennew et al., 2009; Powell et al., 2012; Maciejewska-Mroczek et al., 2018; Alderson \& Morrow, 2020).

\section{Discourse analysis - methodological aspects}

In the analyses and research on childhood studies and the specificity of this current, the following issues are less frequently undertaken: who the child is, how the child develops, what childhood is, and how it differs from adulthood. However, this discourse is still present. At present, it is provided with new ideological perspectives, such as multiculturalism or postcolonialism (Liebel, 2017), which often allow for the development of a discourse that is critical to the approaches that were developed in the 1990s (Oswell, 2013). In many papers which show the issues related to childhood studies, next to undertaking the discussion about the formation itself, the thematic perspectives related to childhood and the situation of children are predominant in the topic profiles. They include, for instance, leisure, culture, migration, ecology, crime, life-support environments and institutions, corporeality, sexuality, violence, health, well-being, religiosity, spirituality, consumerism, economics, and politics (Oswell, 2013; Melton et al., 2014; Vandenhole et al., 2015; Ruck et al., 2017). Topics related to the methodology of research are less frequently visible. Therefore, the aim of the analysis presented in this paper is the issue of methodology of childhood studies. The intention was to present the results of review research conducted in the profile 
of a free (unsystematic) meta-analysis of the discourse. The aim of the research was to identify the preferred methodological solutions in childhood studies and in the discourse related to childhood studies. By means of a review meta-analysis, an attempt was made to identify the preferences for this current of research regarding the general types of research and the methods used. Assuming that the studies presented here were of a preliminary and review nature, the systematic and controlled approach to the selection of material for the analysis was abandoned at this stage in favour of a more free selection of studies that exemplified the discourse of childhood studies and studies that presented research conducted within the ontological and methodological profile of this current of research. This type of solution is also used by other authors who set themselves similar goals and who conduct review meta-analytic methodological research (Qvortrup, 2000, Kehily, 2009; Lange \& Mierendorff, 2009). The analysis covered the papers from the journals dedicated to the dissemination of research that can be included in childhood studies ${ }^{1}$, articles on childhood studies, monographs that show the subject area in a compendious manner ${ }^{2}$, and reports on the situation of children $^{3}$. In a teleological sense, the review analyses aimed to identify patterns of preferred and recommended research types and to identify detailed methodological solutions found and promoted in childhood studies.

\section{Methodological patterns of research in childhood studies}

In the light of the concept of children's rights, it is assumed that the procedures and methods used in research on children should be conceptualised, constructed and used as those that enable children to express freely their own perspecti-

\footnotetext{
${ }^{1}$ As far as journals are concerned, the review analysis focused primarily on the international scientific journal specializing in the dissemination of childhood studies, i.e. "CHILDHOOD". Retrieved 25 October 2020 from: https://journals.sagepub.com/home/chd, but also was partly focused on other substantively relevant journals (e.g. "Child Indicators Research" and "International Journal of Children's Rights" or "Children and Society").

2 The review covered the following: Vandenhole et al., 2015; Melton et al., 2014; Ruck et al., 2017; Radkowska-Walkowicz et al., 2018; Montgomery et al., 2016; Milne, 2013; Archard 2015; Qvortrup et al., 2009; Ben-Arieh et al., 2001; Ben-Arieh \& Frones, 2009; Ben-Arieh et al., 2014; Christensen \& James, 2000; James et al., 2005; James \& James, 2004; James \& James, 2008; Kehily (Ed.) 2001, Berman et al., 2016; Invernizzi et al., 2016; James et al., 2005; Prout, 2005; Wyness, 2006; Gheaus et al., 2019; Todres \& King, 2020.

${ }^{3}$ Reports published by UNICEF and Save The Children from 2000 to 2020. Retrieved from: https://www.unicef.org/research-and-reports; https://www.savethechildren.org/us/about-us/ resource-library.
} 
ves and opinions about situations or problems they experience (Beazley et al., 2009). For this reason, in studies showing specific research, descriptions of the detailed research methods and techniques often occupy a very prominent place (Alderson, 2000; Clark \& Moss, 2005; Lange \& Mierendorff, 2009; Beazley, 2017; Wessells \& Kostelny, 2017). Much attention is also paid to the descriptions of specific principles of how these studies are conducted (Punch, 2002; Soffer \& Ben-Arieh, 2014; Maciejewska-Mroczek et al., 2018).

Due to the specificity of childhood studies, a significant shift in preference for the research methods was reported in their methodological dimension compared to traditional studies on children. The shift was related to the change from methods in which children were the research objects (Mayall, 1999) towards those methods that enabled and emphasized the subjective research relationship with children (Melton et al., 2014; Honig, 2009; Lange \& Mierendorff, 2009).

As a result, researchers reached for methods and techniques that had previously been considered inappropriate or even impossible to use in research on children, such as questionnaires, interviews, discussions, method of episodes (vignettes), participant observation, written accounts, stories or diaries (Clark \& Moss, 2005; Green \& Hogan, 2005). In addition, new research methods began to develop as part of childhood studies. They allowed researchers to capture children's accounts, such as recording audio, video, or photographic accounts by children, transect walks with children, or other methods that allow researchers to enter into a specific relationship with children to learn about their reality (Lange \& Mierendorff, 2009).

A review analysis of the research discourse identified several general types of research preferred in childhood studies which include the following: ethnographic research, macroanalytic research, survey (population-based) studies of children, and longitudinal research.

\section{Ethnography in childhood studies}

The ethnographic approach seems to be the most preferred manner to conduct research in the domain of childhood studies. The broadly understood ethnographic approach, as the one that includes the use of different approaches that enable researchers to capture and highlight an understanding of a given social and symbolic reality (of a given 'world') by its participants (Lange \& Mierendorff, 2009), is considered to be particularly useful against the background of the previously presented assumptions guiding childhood studies. This approach allows to consider children's perspectives and their "voice" in a direct way, and to gain insight into their understanding of the world and their world as such (Prout, 
2002; Emond, 2005; Lange \& Mierendorff, 2009). The ethnographic approach used in childhood studies allows children to speak in a direct research relationship about their own opinions, perceptions, understanding, and meaning of the analysed situations, problems, or environmental conditions in which children live (James \& Prout, 1997; Jenks, 2000; James \& James, 2004; James \& James, 2008; Soffer \& Ben-Arieh, 2014). Thus, the ethnographic approach makes it possible to capture what is particularly important in childhood research, i.e. the subjective images of reality that are reported by children (Kirby \& Webb, 2020). Moreover, it is an approach that favours the participatory participation of children in research, which is generally aimed at in childhood studies (Corsaro \& Molinari, 2000; Lange \& Mierendorff, 2009).

Ethnographic approaches are used in childhood studies for different purposes, for instance to analyse childhood in terms of its nature, or to show the status of children in a community or institution, or children functioning in different specified socio-cultural conditions and communities and to describe specific children's cultures by analysing their codes, meanings, values, and norms (Emond, 2005). They are also useful for capturing the nature of the social organization of the children's world in specific social or situational conditions that determine their functioning (LeVine, 2007; Melton et al., 2014).

Ethnographic approaches are realised in research practice through different specific modes of research. Observation, individual or focus interviews, vignette studies, graphic techniques are frequently used. Less conventional research approaches include photographic or video techniques as well as other specific research techniques used depending on children's abilities (Alderson, 2000; Clark \& Moss, 2005; Green \& Hogan, 2005; Greig et al., 2013; Soffer \& Ben-Arieh, 2014; Favretto et al., 2018).

\section{Macro-analyses}

The role and importance of macro-analyses in childhood research were indicated for instance by Jens Quortrup (2000). According to him, such studies are in fact macro-diagnoses based on specially developed indicators and often based on the so-called big-data. They make it possible to show the general situation of children in demographic, social, health, educational and legal dimensions. Macro-analyses are used in childhood studies both in a fundamental way and as a background for detailed explorations presented by researchers for the purpose of concrete determinations and showing specific situations or problems of children according to subjective or participatory rules. The use of "big data" allows for different interpretations of situations or problems of children in relation to 
different general contexts (e.g. the type of society, the nature of culture, economic conditions, economic or civilization processes), even by referring to historical periods or different generations of children. Such research presents different features and conditions of the realization of childhood, such as education, affluence, health, home conditions, institutionalization of childhood, etc., and explores the determinants of its course. The examples of such research include analyses and reports presented by worldwide organizations for children, such as UNICEF or Save the Children (UNICEF, 2020). Macro-analyses are used in childhood studies as research that presents the situation of children from a general, objectivist perspective, and as research that makes it possible to establish or verify certain correlations. Macro-analyses of childhood often take the form of occasional or systematic reports that monitor the situation of children in relation to their phenomena, problems and living conditions. They are most often based on established standardized indicators showing the general situation and the quality of life of children (reports available on the UNICEF and Save the Children websites) or they illustrate the situation of children in some specific aspect, such as subjective well-being of children (SWBC) (Ben-Arieh, 2012; Casas et al., 2013; Ben-Arieh et al., 2017), health condition, or child labour. The research procedures as part of macro-analyses of childhood are based on research known as big data that takes advantage of various large-scale research (conducted on very large populations of children or adults e.g. parents, teachers, doctors, etc.) and are administrative research based on data obtained from existing statistics conducted by various agencies and departments (George \& Lee, 2014). Thus, macro-analyses primarily use a variety of macro data, administrative, statistical, and institutional data, and also the data from various detailed studies and reports (Bradshaw et al., 2013). A key issue in macro-analytic research is the selection of indicators showing the situation of children. Their type and quality are important. The examples include the traditional indicators which have been used for a long time to monitor the situation of children (e.g. used by UNICEF such as the under-five mortality rate; U5MR), enrolment rate, the prevalence of risky behaviours among children or life satisfaction (UNICEF, 2017). Of interestingly, he issue of indicators showing the situation of children or their well-being, which are the basis (subject) of macro-analyses, has become a field of dynamically developing sub-discourse and research (Ben-Arieh \& Goerge, 2001; Ben Arieh et al., 2001; Ben Arieh, 2006; Ben Arieh \& Frones, 2009; Ben-Arieh et al., 2009; Ben-Arieh \& Frones, 2011; George \& Lee, 2014). Currently, it is a specific current of research within childhood studies which is termed "the child indicators movement" by some people (Ben-Arieh, 2008, 2006). It should 
also be added that in line with the principles of childhood studies, the participatory role of children in the processes of creating and establishing macro-indicators depicting childhood is now strongly emphasized (Ben-Arieh, 2005).

According to Jens Qvortrup (2000), macro-analyses offer many opportunities for revealing the nature and quality of childhood, especially when used in a variety of comparative settings (as comparative research) and in the dimension of historical, intergenerational or cross-cultural analyses. Macro-analyses are also a functional methodological approach in the perspective of their use in comparative studies which are based on the country cases (countries as instances or case countries). In the former, individual countries are the examples representing the situation of children or their problems in different or similar state realities. Comparative research on changes in childhood in both parts of Germany (East and West) and in the Netherlands, from the perspective of analysing factors such as institutionalisation of childhood, individualisation, children's autonomy, children's activities and the use of social networks, and the analysis of childhood in these dimensions in the context of its environmental differentiation (i.e. realisation in big cities, towns and villages) is given as an example of countries as instances by Qvortrup (2000).

In the latter, when the research is based on case countries, the analyses are related to situations or specific problems of children in a comparative overview of several different countries representing the groups of countries which are similar to each other due to certain geographical, socio-cultural, economic and other features. Research on the occurrence and risk factors of violence against children conducted in different countries (Vietnam, Italy, Peru and Zimbabwe) is an example of case countries (Maternowska et al., 2016, 2018).

\section{Population survey research among children}

Another type of research common in childhood studies includes quantitative research (population research) based on samples of children representing larger groups or other collectivities. It is used to show life situations of children, their behaviours, problems they experience, their quality of life or well-being reported or explicitly assessed in their subjective perspective (Greig et al., 2013). This research constitutes an important current in childhood studies allowing for the quantitative characterization of phenomena, the generalization of conclusions and the verification of some conditions and relationships (Bradshaw et al., 2013; Casas et al., 2011; Casas et al., 2013). It can be conducted through the use of different techniques and tools. One example is questionnaire surveys based either on typical but child-matched survey questions or on measurement sca- 
les. The examples of the latter are standardized scales used worldwide, such as The Overall Life Satisfaction (Casas \& Rees, 2015), Briere's Trauma Symptom Checklist for Children (Greig et al., 2013) or Children's Subjective Well-Being Index (CWEBI) (Grane et al., 2019). The first example is a scale of children's subjective assessment of their life, evaluation of their functioning conditions, while the second scale is based on the assessment of the degree to which children experience some problems. In turn, CWEBI is a proposal of Spanish researchers who used a questionnaire consisting of 50 items in 7 thematic groups to examine well-being of almost three thousand children and compared the results for Spanish provinces. Of note, survey research is often used as part of childhood studies in the comparative profile. Another example is related to comparative research on the subjective well-being of children under 13 years of age conducted in several countries such as Algeria, Republic of South Africa, Israel and Spain (Gonzales-Carasco et al., 2018). This research is conducted as part of a broader initiative known as International Survey of Children Well-Being (ISCWeB) ${ }^{4}$, which includes the implementation of systematic comparative studies of children's well-being in different countries. This research uses the same methodology and tools (scales as part of questionnaires given to children). The subjective well-being of children is correlated with various variables, i.e. individual, environmental or territorial features of children (Rees et al., 2017), or, for example, with the religious context of children's functioning (Kosher \& Ben-Arieh, 2017). This research has also been conducted in Poland since 2016 (http://www.isciweb.org/?CategoryID=157; Strózik et al., 2016).

To ensure the participatory profile of population research postulated in childhood studies, researchers more increasingly consult or cooperate with children to form the questions and questionnaires that are used in such research.

\section{Longitudinal studies}

Longitudinal studies are also used in childhood studies. They are aimed at showing the transformation of childhoods in a temporal profile or showing the importance of different social, socio-economic or political breakthroughs on the quality of childhood or certain characteristics or parameters of childhood in the same groups or cohorts of children (Qvortrup, 2000; Dworsky, 2014). As an example of such research, Qvortrup indicated the research by Kirchhofer (1998), who conducted studies for some period of time from the early 1990s in a group of children in East Berlin to capture the significance of the political

${ }^{4}$ For a description of the ongoing project, see: http://www.isciweb.org/?CategoryID=157. 
transformation from socialism to capitalism for the quality of childhood and the conditions of children's functioning.

In childhood studies, longitudinal studies are based on the data obtained directly from children. They are often related to the consequences of some phenomena or processes in the developmental context, which are monitored for some time in a particular group of children under study. Studies that focus on specific populations of children, such as children who take advantage of the welfare system, those who participated in some therapeutic or early intervention programs (Dworsky, 2014), children at crime risk or children with other specific features (Pells et al., 2016) are common.

\section{On the status of children in childhood studies and its ethical significance}

The concepts of children's rights, emancipation of children, their subjective and equal status on the basis of which childhood studies develop (Vanobbergen, 2015) result in the fact that respecting children's subjectivity, protecting their rights and realizing their participatory rights as research participants (Corsaro, 2015), including aiming at active participation of children at all stages of research are crucial for the methodology next to the solutions indicated in the paper.

This means that children should cooperate with adult researchers at every stage of the research process, from its design to its description and the use of its results in social practice. Therefore, there is a methodological transformation in childhood studies involving reorientation of the position of children in research compared to previous research on children. There is a shift from research "on children" or "about children" to research "with children". Children are not objects of research but gain the status of researchers of their reality (children as researchers) (Ben -Arieh, 2005; Kellet, 2010; Mason \& Danby, 2011; Habashi, 2013; Greig et al., 2013; O’Reilly et al., 2013; Dahl, 2014; Mason \& Watson, 2014; Shier, 2015).

In various characteristics of childhood studies (Shier, 2015) attention is also paid to encouraging young people to investigate problems that concern them independently and only with the support of adults. The rule of research participation of children implies the recognition of children as those who are entitled and capable of initiating research about their reality and problems, conducting research as independently as possible, only with the support, help or assistance of adults (research by children) (Kellet, 2010; Bucknall, 2012; Dahl, 2014; Shier, 2015). In demonstrating the change in the status of children in 
research, Mary Kellet (2010, pp. 22, 23, 83) systematized the research relationships between adults and children that can be identified in the history into research on, about, with and by children.

Childhood studies are part of the current of new research methodology related to the realisation of the concepts of democratization and social emancipation (in terms of group and community dimensions) that is participatory research (Boyden \& Ennew, 1997; Jason et al., 2004; Veale, 2005). The change of the position of children in research has ethical significance in addition to methodological meaning. The use of participatory research with or realised by children, especially as participatory action research has a particularly strong ethical dimension (Boyden \& Ennew, 1997). Then children's subjectivity is deeply understood, respected and realised. Moreover, it becomes ethically significant that participation in research has both personal and group-related benefits for children (Kellet, 2010; Greig et al., 2013; Dahl, 2014). Participatory research with children is recommended not only because it allows for obtaining a true, accurate picture of childhood and a better understanding of children's experiences, but also because it provides children with an empowering experience by fostering a sense of their own subjectivity. Moreover, children learn the importance of research in solving various problems. They also learn different research activities through which they can develop their competence as co-researchers and researchers of their own reality and problems over time (Greig et al., 2013). Thus, participatory research is an empowerment activity, as it develops and strengthens active attitude of children in acting for themselves, their environment, their social group and generally teaches an active attitude in solving various problems.

\section{Conclusions}

Undoubtedly, the methodological patterns of childhood studies identified and presented in this paper do not exhaust the rich field of different methodological possibilities that the researchers representing this current of research reach for. In the light of the presented analyses and proposed systematization, it may be concluded that methodological solutions applied in childhood studies constitute a rich area of possibilities for investigating and showing the image and problems of childhood. Based on the established features, i.e. methodological principles of this current of research, researchers can reach for various solutions and they do so. At the same time, to a large extend, but not exclusively, they are guided by a concern to reconstruct in research the subjective image of reality 
experienced by children. With this intention, the group of methods, including visual methods, is more widely applied gaining popularity and is dynamically expanded. Also, the current of including children in the research process (children as researchers of their own reality) is dynamised.

When exploring the issue of the methodology of childhood studies, researchers can and should certainly refer to the various methodological specifications on this subject, which can be found in the global discourse, the authors of which present various other proposals for systematization (Qvortrup, 2000; Lange \& Mierendorff, 2009; Corsaro, 2015). The author's proposal resulting from an overview analysis of the discourse on childhood studies and the research discourse as part of childhood studies is certainly characterized by shortcomings and is not perfect. Nevertheless, the aim of this study was also to develop a methodological discourse on childhood studies in which there is some shortage and to inspire other researchers to join in. The area of childhood research methodology analysed in the paper should definitely be perceived as dynamically developing, the monitoring of which seems to be an interesting research task in itself.

\section{References}

Alderson, P. (2000). Children as Researchers: The Effect of Participation Rights on Research Methodology. In: P. Christiansen, \& A. James (Eds.), Research with Children. Perspectives and Practices (pp. 241-257). London-New York: Falmer Press.

Alderson, P., \& Morrow, V. (2020). The Ethics of Research with Children and Young People. London: SAGE.

Archard, D. (2015). Children. Rights and Childhood. Third Edition. London-New York: Routledge.

Aries, P. (1995). Historia dzieciństwa. Dziecko i rodzina $w$ dawnych czasach [History of Childhood. Child and the Family in the Past Times]. Gdańsk: Wydawnictwo Marabut.

Beazley, H. (2017). Visual Methods in Participatory Right-Based Research with Children and Young People in Indonesia and Vanuatu. In: M.D. Ruck, M. Peterson-Badali, \& M. Freeman (Eds.), Handbook of Children's Rights. Global and Multidisciplinary Perspectives (pp. 550-578). New York-London: Routledge.

Beazley, H., Bessell, S., Ennew, J., \& Waterson, R. (2009). The Right to be Properly Researched: Research with Children in a Messy, Real World. Children's Geographies, 4(7), 365-378, doi: 10.1080/14733280903234428. 
Ben Arieh, A. (2005). Where are the Children? Children's Role in Measuring and Monitoring Their Well- Being. Social Indicators Research, 74(3), 573-596, doi: 10.1007/s11205004-4645-6.

Ben-Arieh, A. (2006). Measuring and Monitoring the Well-Being of Young Children Around the World. Retrieved 10 February from: http://unesdoc.unesco.org/images/0014/001474/147444e.pdf.

Ben-Arieh, A. (2012). How do We Measure and Monitor the "State of our Children"? Revisiting the Topic in Honor of Sheila B. Kamerman. Children and Youth Services Review, 34(3), 569-575, doi: 10.1016/j.childyouth.2011.10.008.

Ben-Arieh, A. (2014). The Settings of Childhood. In: G.B. Melton, A. Ben-Arieh, J. Cashmore, G.S. Goodman, \& N.K. Worley (Eds.). The SAGE Handbook of Child Research (pp. 31-37). London: SAGE.

Ben-Arieh, A., Casas, F., Frønes, I., \& Korbin, J.E. (Eds.) (2009). Handbook of Child Well-Being Theories, Methods and Policies in Global Perspective. Dordrecht-London: Springer.

Ben-Arieh, A., \& Frones, I. (Eds.) (2009). Indicators of Children's Well-Being: Theory and Practice in a Multi-Cultural Perspective. New York: Springer-Verlag.

Ben-Arieh, A., \& Goerge, R. (2001). Beyond the Numbers: How do We Monitor the State of Our Children. Children and Youth Service Review, (23)8, 603-631, doi: 10.1016/ S0190-7409(01)00150-5.

Ben-Arieh, A., Kaufman, N., Andrews, A., George, R., Lee Bong, Joo, \& Lawrence Aber, J. (Eds.) (2001). Measuring and Monitoring Children's Well-Being. Dodrecht: Kluwer Academic.

Ben Arieh, A., Rees, G., \& Dinisman, T. (2017). A Comparative View of Children's Subjective Well-Being: Findings from the Second Wave of the ISCWeB Project. Children and Youth Services Review, 80, 1-2, doi: 10.1016/j.childyouth.2017.06.068.

Boyden, J., \& Ennew, J. (Eds.) (1997). Children in Focus: A Manual for Participatory Research with Children. Stockholm: Save the Children Sweden.

Bradshaw, J., Martorano, L., Natali, L., \& de Neubourg, C. (2013). Children's Subjective Well-being in Rich Countries, Working Paper 2013-03. Florence: UNICEF Office of Research Innocenti. Retrieved from 15 October 2021: http://www.unicef-irc.org/publications/pdf/iwp_2013_3.pdf.

Bucknall, S. (2012). Children as Researchers in Primary Schools. Choice, Voice, and Participation. London: Routledge. 
Casas, F., (2000). Quality of Life and the Life Experience of Children, Ghent. Retrieved 15 October 2021 from: https://www.researchgate.net/publication/292681804_Childre$\mathrm{n} \% 27 \mathrm{~s}$ quality_of_life.

Casas, F., \& Rees, G. (2015). Measures of Children's Subjective Well-Being: Analysis of the Potential for Cross-National Comparisons. Child Indicators Research, 8(1), 49-69, doi: 10.1007/s12187-014-9293-Z.

Casas, F., Sarriera, J.C., Abs, D., Coenders, G., Alfaro, J., Saforcada, E., \& Tonon, G. (2011). Subjective Indicators of Personal Well-Being Among Adolescents. Performance and Results for Different Scales in Latin Language Speaking Countries: a Contribution to the International Debate. Child Indicators Research, 5(1), 1-28, doi: 10.1007/s12187011-9119-1.

Casas, F., Tiliouine, H., \& Figuer, C. (2013). The Subjective Well-Being of Adolescents from Two Different Cultures: Applying Three Versions of the PWI in Algeria and Spain. Social Indicators Research, 2(115), 637-651, doi: 10.1007/s11205-012-0229-z.

Christensen, P., \& James, A. (Eds.) (2000). Research with Children. Perspectives and Practices. London-New York: Falmer Press.

Clark, A., \& Moss, P. (2005). Listening to Young Children. The Mosaic Approach. London: National Children's Bureau and JR Foundation.

Corsaro, W. (2015). The Sociology of Childhood, $4^{\text {th }}$ ed. Los Angeles: SAGE.

Corsaro, W., \& Molinari, L. (2000). Entering and Observing in Children's Worlds: a Reflection on a Longitudinal Ethnography of Early Education in Italy. In: P. Christensen, \& A. James (Eds.), Research with Children. Perspectives and Practices (pp. 179-200). London-New York: Falmer Press.

Dahl, T.I. (2014). Children as Researchers: We Have a Lot to Learn. In: G.B. Melton, A. Ben-Arieh, J. Cashmore, G.S. Goodman, \& N.K. Worley (Eds.), The SAGE Handbook of Child Research (pp. 593-618). London: SAGE.

Dworsky, A. (2014). Children as Self-Informants in Longitudinal Studies: Substantive Findings and Methodological Issues. In: G.B. Melton, A. Ben-Arieh, J. Cashmore, G.S. Goodman, \& N.K. Worley (Eds.), The SAGE Handbook of Child Research (pp. 391-431). London: SAGE.

Emond, R. (2005). Ethnographic Research Methods with Children and Young People. In: S. Green, \& D. Hogan (Eds.), Researching Children's Experience (pp. 123-140). London: SAGE.

Ennew, J., Abebe, T., Bangyani, R., Karapituck, P., Kjørholt, A.T, \& Noonsup, T. (2009). The Right to be Properly Researched: How to Do Rights-Based, Scientific Research 
with Children. A Set of Ten Manuals for Field Researchers. Bangkok: Black on White Publications, Norwegian Center for Child Research and World Vision International.

Favretto, A.R., Fucci, S., \& Zaltron, F. (2018). Codzienne praktyki w zdrowiu i chorobie. Metodologiczne rozważania nad kompetencjami dzieci [Everyday Practices in Health and Illnes. Methodological Considerations on Children's Competencies]. In: M. Radkowska-Walkowicz, \& M. Reiman (Eds.), Dzieci i zdrowie. Wstęp do childhood studies [Children and Health. Introduction Into Childhood Studies]. Warszawa: Oficyna Naukowa.

Garbula, J., \& Kowalik-Olubińska, M. (2021). Konstruowanie obrazu dzieciństwa w perspektywie psychologicznej i socjokulturowej [Constructing a Picture of Childhood in a Psychological and Sociocultural Perspective]. Przegląd Pedagogiczny, 1, 25-34.

Gheaus, A., Calder, G., \& DeWispelaere, J. (Eds.) (2019). The Routledge Handbook of the Philosophy of Childhood and Children. London: Routledge.

Goerge, R., \& Lee, B.J.(2014). Use of Administrative Data in ChildhoodResearch.In: G.B. Melton, A. Ben-Arieh, J. Cashmore, G.S. Goodman, \& N.K. Worley (Eds.), The SAGE Handbook of Child Research (pp. 432-442). London: SAGE.

Gonzales-Carasco, M., Casas, F., Ben-Arieh, A., Savahl, S., Tiliouine, H. (2018). Children's Perspectives and Evaluations of Safety in Diverse Settings and Their Subjective Well-Being: A Multi-National Approach. Applied Research Quality Life, 14, 309-334, doi: 10.1007/s11482-018-9594-3.

Graham, A., Powell, M., Taylor, N., Anderson, D., \& Fitzgerald, R. (2013). Ethical Research Involving Children. Florence: UNICEF Office of Research Innocenti.

Grane, A., Albarran, I., \& Arribas-Gil, A. (2019). Constructing Children's Subjective Well-Being Index: an Application to Socially Vulnerable Spanish Children. Child Indicators Research, 13, 1235-1254, doi: 10.1007/s12187-019-09692-w.

Greig, A., Taylor, J., \& MacKay, T. (2013). Doing Research with Children. A Practical Guide. London: SAGE.

Green, S., \& Hogan, D. (Eds.) (2005). Researching Children's Experience. Methods and Approaches. London: SAGE.

Habashi, J. (2013). Children Writers: Methodology of the Rights-Based Approach. International Journal of Children's Rights, 21, 12-24, doi: 10.1163/157181812X634229.

Hill, M. (2005). Ethical Considerations in Researching Children's Experience. In: S. Green, \& D. Hogan (Eds.), Researching Children's Experience (pp. 61-86). London: SAGE.

Honig, M.S. (2009). How is the Child Constituted in Childhood Studies? In: J. Qvortrup, W. Corsaro, \& M.S. Honig (Eds.), The Palgrave Handbook of Childhood Studies (pp. 62-77). Basingstoke: Palgrave Macmillan. 
Invernizzi, A., Liebel, M., Milne, B., \& Budde, R. (Eds.) (2016). “Children out of Place” and Human Rights. In Memory of Judith Ennew. New York: Springer.

James, A., \& James, A. (2008). European Childhoods: Cultures, Politics and Childhoods in Europe. Basingstoke: Palgrave Macmillan.

James, A., \& James, A. (2008). Key Concepts in Childhood Studies. Los Angeles: SAGE.

James, A., \& James, A. (2004). Constructing Childhood: Theory Policy and Social Practice. Basingstoke: Palgrave Macmillan.

James, A., Jenks, C., \& Prout, A. (2005). Theorizing Childhood. Cambridge: Polity Press.

James, A., \& Prout, A. (Eds.) (1997). Constructing and Reconstructing Childhood: Contemporary Issues in the Sociological Study of Childhood. London-Washington: Falmer Press.

Jason, L., Keys, C., Suarez-Balcazar, Y., Taylor, R., \& Davies, M. (Eds.) (2004). Participatory Community Research. Theories and Methods in Action. Washington: American Psychology Association.

Jenks, C. (2000). Zeitgeist Research on Childhood. In: P. Christiansen, \& A. James (Eds.), Research with Children. Perspectives and Practices (pp. 62-76). London: Falmer Press.

Kehily, M.J. (Ed.) (2009). An Introduction to Childhood Studies. Second Edition. Berkshire: Open University Press.

Kellett, M. (2010). Children as Active Researchers: a New Research Paradigm for the $21^{\text {st }}$ Century? ESRC, UK. Retrieved 13 February 2021 from: http://oro.open.ac.uk/7539/1/.

Kirby, P., \& Webb, R. (2020). Taking Part, Joining in and Being Heard? Ethnographic Explorations of Children's Participation. In: J. Todres, \& S.M. Kong (Eds.), The Oxford Handbook of Children's Rights Law (pp. 477-494). New York: Oxford University Press.

Kosher, H., \& Ben-Arieh, A. (2017). Religion and Subjective Well-Being among Children: A Comparison of Six Religion Groups. Children and Youth Service Review, 80, 63-77, doi: 10.1016/j.childyouth.2017.06.049.

Lange, A., \& Mierendorff, J. (2009). Method and Methodology in Childhood Research. In: J. Qvortrup, W. Corsaro, \& M.S. Honig (Eds.), The Palgrave Handbook of Childhood Studies (pp. 78-96). Basingstoke: Palgrave Macmillan.

LeVine, R.A. (2007). Ethnographic Studies of Childhood: A Historical Overview. American Anthropologist, (109)2, 247-260, doi: 10.1525/aa.2007.109.2.247.

Liebel, M. (2017). Children without Childhood? Against the Postcolonial Capture of Childhoods in the Global South. In: A. Invernizzi, M. Liebel, B. Milne, \& R. Budde (Eds.), "Children Out of Place” and Human Rights. In Memory of Judith Ennew (pp. 79-97). New York: Springer. 
Maciejewska-Mroczek, E., Radkowska-Walkowicz, M., Reimann, M., \& Witeska-Młynarczyk, A. (2018). Kodeks dobrych praktyk w badaniach prowadzonych z perspektywy nauk społecznych [Code of Good Practices in Research Conducted from a Perspective of Social Sciences]. In: M. Radkowska-Walkowicz, \& M. Reiman (Eds.), Dzieci i zdrowie. Wstep do childhood studies [Children and Health. Introduce to Childhood] (pp. 27-34). Warszawa: Oficyna Naukowa.

Mason, J., \& Watson, E. (2014). Researching Children: Research on, with, and by Children. In: A. Ben-Arieh, F. Casas, I. Frønes, \& J.E. Korbin (Eds.), Handbook of Child Well-Being. Theories, Methods and Policies in Global Perspective (pp. 27-57). Dordrecht-London: Springer.

Mason, J., \& Danby, S. (2011). Children as Experts in their Lives: Child Inclusive Research. Child Indicators Research, 4(2), 185-189, doi: 10.1007/s12187-011-9108-4.

Maternowska, C.M., Potts, A., \& Fry, D. (2016). The Multi-Country Study on the Drivers of Violence Affecting Children. Florence: UNICEF Office of Research Innocenti. Retrieved 12 February 2019 from: https://www.unicef-irc.org/e-book/THE-MULTI-COUNTRY-STUDY-PAGER/HTML/.

Maternowska, C.M., Potts, A., Fry, D., \& Casey, T. (2018). Research that Drives Change: Conceptualizing and Conducting Nationally Led Violence Prevention Research. Florence: UNICEF Office Of Research Innocenti.

Mayall, B. (1999). Children and Childhood. In: S. Hood, B. Mayall, \& S. Oliver (Eds.), Critical Issues in Social Research: Power and Prejudice (pp. 10-24). Buckingham: Open University Press.

Melton, G., Gross-Manos, D., Ben-Arieh, A., \& Yazykova, E. (2014). The Nature and Scope of Child Research: Learning About Children's Lives. In: G.B. Melton, A. Ben-Arieh, J. Cashmore, G.S. Goodman, \& N.K. Worley (Eds.), The SAGE Handbook of Child Research (pp. 3-28). London: SAGE.

Melton, G.B., Ben-Arieh, A., Cashmore, J., Goodman, G.S., \& Worley, N.K. (Eds.) (2014). The SAGE Handbook of Child Research. London: SAGE.

Milne, B. (2013). The History and Theory of Children's Citizenship in Contemporary Societies. Dordrecht: Springer.

Moody, Z., \& Darbellay, F. (2019). Studying Childhood, Children and Their Rights: The Challenge of Interdisciplinarity. Childhood, 26(1), 8-21, doi: 10.1177/0907568218798016.

Morrow, V. (2008). Ethical Dilemmas in Research with Children and Young People About Their Social Environments. Children's Geographies, 6(1), 49-61, doi: $10.1080 / 14733280701791918$. 
O'Reilly, M., Ronzoni, P., \& Dogra, N. (2013). Research with Children. Theory and Practice. London: SAGE.

Oswell, D. (2013). The Agency of Children. From Family to Global Human Rights. Cambridge: Cambridge University Press.

Pells, K., Portella, M.J.O., \& Espinoza-Revollo, P. (2016). Experiences Of Peer Bullying Among Adolescents and Associated Effects on Young Adult Outcomes: Longitudinal Evidence from Ethiopia, India, Peru and Viet Nam. Florence: UNICEF Office of Research Innocenti. Retrieved 12 February 2019 from: /https://www.unicef-irc.org/publications $/ 863 /$.

Powell, M.A., Fitzgerald, R., Taylor, N.J., \& Graham, A. (2012). International Literature Review: Ethical Issues in Undertaking Research with Children and Young People (Literature review for the Childwatch International Research Network). Lismore: Southern Cross University, Centre for Children and Young People.

Prout, A. (2005). The Future of Childhood. Toward the Interdisciplinary Study of Children. London: Routledge.

Punch, S. (2002). Research with Children. The Same or Different from Research with Adults? Childhood, 9(3), 321-341, doi: 10.1177/0907568202009003005.

Qvortrup, J. (2000). Macroanalysis of childhood. In: P. Christiansen, \& A. James (Eds.), Research with Children. Perspectives and Practices (pp. 77-97). London-New York: Falmer Press.

Qvortrup, J., Corsaro, W., \& Honig, M.S. (Eds.) (2009). The Palgrave Handbook of Childhood Studies. Basingstoke: Palgrave Macmillan.

Radkowska-Walkowicz, M., \& Reiman, M. (Eds.) (2018). Dzieci i zdrowie. Wstęp do childhood studies [Children and Health. Introduction into Childhood Studies]. Warszawa: Oficyna Naukowa.

Rees, G., \& Dinisman, T. (2015). Comparing Children's Experiences and Evaluations of Their Lives in 11 Different Countries. Child Indicators Research, 8, 5-31, doi: 10.1007/ s12187-014-9291-1.

Ruck, M.D., Peterson-Badali, M., \& Freeman, M. (Eds.) (2017). Handbook of Children's Rights. Global and Multidisciplinary Perspectives. New York-London: Routledge.

Shier, H. (2015). Children as Researchers in Nicaragua: Children's Consultancy to Transformative Research. Global Studies of Childhood, 5(2), 206-219, doi: $10.1177 / 2043610615587798$.

Soffer, M., \& Ben-Arieh, A. (2014). School Aged Children as Sources of Information About Their Lives. In: G.B. Melton, A. Ben-Arieh, J. Cashmore, G.S. Goodman, \& N.K. Worley (Eds.), The SAGE Handbook of Child Research (pp. 555-574). London: SAGE. 
Strózik, D., Strózik, T., \& Szwarc, K. (2016). The Subjective Well-Being of School Children. The First Findings from the Children's Worlds Study in Poland. Child Indicators Research, 9, 39-50, doi: 10.1007/s12187-015-9312-8.

Śliwerski, B. (2020). Badania nad małym dzieckiem i dzieciństwem [Research on the Young Child and Childhood]. Konteksty Pedagogiczne, 2(15), 9-24, doi: 10.19265/ $\mathrm{kp} .2020 .2 .15 .266$.

Todres, J., \& Kong, S.M. (Eds.) (2020). The Oxford Handbook of Children's Rights Law. New York: Oxford University Press.

UNICEF (2017). Building the Future. Children and the Sustainable Development Goals in Rich Countries. Florence: UNICEF Innocenti Report Card 14.

UNICEF (2020). Best of UNICEF Research and Evaluation 2020. Florence: UNICEF Office of Research Innocenti.

Vandenhole, W., Desmet, E., Reynart, D., \& Lembrechts, S. (Eds.) (2015). Routledge International Handbook of Children's Rights Studies. London-New York: Routledge.

Vanobbergen, B. (2015). Children Rights and Childhood Studies; From Living Apart Together Towards a Happy Marriage. In: W. Vandenhole, E. Desmet, D. Reynart, \& S. Lembrechts (Eds.), Routledge International Handbook of Children's Rights Studies (pp. 60-76). London-New York: Routledge.

Veale, A. (2005). Creative Methodologies in Participatory Research with Children. In: S. Greene, \& D. Hogan (Eds.), Researching Children's Experience (pp. 253-272). London: SAGE.

Weller, D., Hobbs, S.D., \& Goodman, G.S., (2014). Challenges and Innovations in Research on Childhood. In: G.B. Melton, A. Ben-Arieh, J. Cashmore, G.S. Goodman, \& N.K. Worley (Eds.), The SAGE Handbook of Child Research (pp. 363-370). London: SAGE. 